\title{
Environmental Tribalism
}

\author{
Douglas A. Kysar ${ }^{\dagger}$ and James Salzman ${ }^{\dagger \dagger}$
}

\section{INTRODUCTION}

In August 2001, the prestigious academic publishing house, Cambridge University Press, launched a book called The Skeptical Environmentalist. ${ }^{1}$ Written by Bjørn Lomborg, an Associate Professor of Statistics at the University of Aarhus in Denmark, the book challenged popular perceptions that the global environment is getting worse. Lomborg argued that concerns we hear over the "Litany" of environmental harmsloss of biodiversity, climate change, overpopulation, deforestation, etc.-are not supported by the evidence. ${ }^{2}$ Contrary to claims by environmental groups reported in the popular press, "our problems are getting smaller and not bigger, and ... frequently the offered solutions are grossly inefficient." Bolstering his views on the "Real State of the

$\dagger$ Assistant Professor of Law, Cornell Law School.

t† Professor of Law, Washington College of Law, American University. The authors are grateful for the insights of John Baden and Pete Geddes, who suggested the metaphors of cutting gates and tribalism. Helpful comments were also generously provided by Dan Farber, J.B. Ruhl, Todd Zywicki, and Sandy Gaines. David Gacioch provided excellent research assistance.

1. BJøRN LOMBORG, THE SKePtiCal ENVIRONMENTALIST: MEASURING THE REAL STATE OF THE WORLD (2001).

2. See id. at 329 . Lomborg states that

[w]e will not lose our forests; we will not run out of energy, raw materials, or water. We have reduced atmospheric pollution in the cities of the developed world and have good reason to believe that this will also be achieved in the developing world. Our oceans have not been defiled, our rivers have become cleaner and support more life .... Nor is waste a particularly big problem.

The problem of the ozone layer has been more or less solved. The current outlook on the development of global warming does not indicate a catastrophe.... And, finally, our chemical worries and Id.

fear of pesticides are misplaced and counterproductive.

3. Id. at 5. Lomborg is by no means the first to make such claims. See, e.g., GREGG EASTERBRooK, MOMENT ON EARTH: THE COMING AGE OF EnVIRonMental OPTIMISM 16-18 (1996); JUlian L. Simon, The Ultimate 
World" with over 2,900 footnotes, Lomborg made a strong claim, and the responses have been equally strong.

The Economist, for instance, called it "one of the most valuable books on public policy-not merely on environmental policy-to have been written for the intelligent general reader in the past ten years ... 'The Skeptical Environmentalist' is a triumph."4 Not to be outdone, the British newspaper, The Daily Telegraph, called it "probably the most important book on the environment ever written." 5 A host of other publications and, notably, conservative groups similarly lauded the book's merits. ${ }^{6}$ This adulation was countered by equally zealous condemnation. A review in the eminent scientific journal, Nature, denounced the book as "deeply flawed" and implicitly likened Lomborg to Holocaust deniers. ${ }^{7}$ Under the heading,

RESOURCE 5-8 (1981) [hereinafter THE Ultimate ResouRCE]; JULian L. Simon, THE Ultimate RESOURCE 2, at 5-9 (1996) (hereinafter THE Ultimate Resource 2]; The State of Humanity 1-2 (Julian L. Simon ed., 1995); Ronald Bailey, The Progress Explosion: Permanently Escaping the Malthusian Trap, in EARTh RePORT 2000: Revisiting THE TRUe State OF THE Planet 1, 7-21 (Ronald Bailey ed., 2000).

4. Doomsday Postponed, The ECONOMIST, Sept. 8, 2001, at 89, 89-90 (book review).

5. Matt Ridley, The Greens Have Got It Wrong, THE DaIly TelegraPH (UK), http://www.telegraph.co.uk (Aug. 25, 2001) (book review).

6. For instance, the New York Times hailed The Skeptical Environmentalist as "a substantial work of analysis" that exposes the "urban myths" of the environmental agenda. Nicholas Wade, Bjorn Lomborg: From an Unlikely Quarter, Eco-Optimism, N.Y. TIMES, Aug. 7, 2001, at F1 (book review). A reviewer in the Washington Post agreed, calling the work a "massive, meticulously presented argument," "a factual encyclopedia," "a magnificent achievement," and "the most significant work on the environment since... Rachel Carson's Silent Spring, in 1962." Denis Dutton, Greener Than You Think, WASH. POST, Oct. 21, 2001, at BW1 (book review). Ronald Bailey of the Competitive Enterprise Institute concluded that Lomborg's "magnificent and important book ... deals a major blow to [environmentalism] by superbly documenting a response to environmental doomsaying." Ronald Bailey, Debunking Green Myths: An Environmentalist Gets It Right, REASON, Feb. 2002, at 58, 58 (book review). More recently, Judge Alex Kozinski provided a particularly laudatory review in the pages of the Michigan Law Review, calling The Skeptical Environmentalist "an indispensable resource" that provides "a balanced, thoughtful approach to environmental problems." Alex Kozinski, Gore Wars, 100 MICH. L. REV. 1742, 1746 (2002) (book review).

7. "The text employs the strategy of those who, for example, argue that gay men aren't dying of AIDS, that Jews weren't singled out by the Nazis for extermination, and so on." Stuart Pimm \& Jeff Harvey, No Need to Worry About the Future, 414 NATURE 149, 149 (2001) (book review). A commentator in the Weekly Standard, in turn, defended Lomborg by comparing environmentalists to followers of "fanatical Islam." James K. Glassman, Green 
"Science defends itself against The Skeptical Environmentalist," Scientific American devoted a special section of eleven pages to critiques of Lomborg's treatment of climate change, biodiversity, and other topics. ${ }^{8}$ Equally critical articles and reports were published around the globe (including one by Lomborg's own former colleagues at the University of Aarhus). ${ }^{9}$ Such detractors argued that Lomborg's "Litany" was an outdated list of straw men, his use of data was misleadingly selective, his treatment of issues showed basic scientific ignorance, and worse. ${ }^{10}$ The most demonstrative negative review came in the form of a pie thrown in Lomborg's face during a book signing event at Oxford. ${ }^{11}$

Given Lomborg's claims, it's not surprising that reactions to his book-ranging from a threatened boycott of Cambridge University Press ${ }^{12}$ to the Danish government's appointment of Lomborg to head a new national environmental institute ${ }^{13}$ have been so strong. What has been surprising, though, is the starkly bipolar nature of the reactions, for there are precious few moderate reviews or stories to be found on The Skeptical Environmentalist. It seems either to be described as a carefully researched unmasking of the environmental movement's scare tactics or as an unprincipled, ill-informed, tendentious book. ${ }^{14}$

With Rage, WKLY. STANDARD, Feb. 25, 2002, at 14, 16.

8. See John Rennie, Misleading Math About the Earth: Science Defends Itself Against the Skeptical Environmentalist, SCI. AM., Jan. 2002, at 61, 61.

9. A number of these critiques have been posted on the web at http://www.anti-lomborg.com. A particularly accessible account comes from Tom Burke. See Tom Burke, Ten Pinches of Salt: A Reply to Bjorn Lomborg, at http://www.green-alliance.org.uk/Documents/Reports/ten\%20pinches $\% 20$ of\%20salt.pdf (last visited Mar. 3, 2003).

10. "As science writing goes, The Skeptical Environmentalist is C-minus stuff, as straight-forward and lackluster as a 10th-grade term paper." Kathryn Schulz, Let Us Not Praise Infamous Men: On Bjorn Lomborg's Hidden Agenda, GRIST MAG., http://www.gristmagazine.com/books/schulz121201.asp (Dec. 12, 2001).

11. See Russ Baker, The Lomborg File: When the Press is Lured by a Contrarian's Tale, 40 Colum. JouRnALISM REv. 78, 78 (2002). A60.

12. See Andrew Goldstein, Danish Darts, TIME, Aug. 26, 2002, at A60,

13. See Kozinski, supra note 6 , at 1745 n.20.

14. Compare id. at 1746 (describing Lomborg's book as "a devastating critique of the environmental scare-mongering of the last three decades"), Bailey, supra note 6, at 59 ("[Lomborg] shows how, time and again, ideological environmentalists misuse, distort, and ignore the vast reams of data that contradict their dour visions."), Dutton, supra note 6 ("Lomborg found on close analysis that the factual foundation on which the environmental doomsayers 
Viewed from the outside, Lomborg's book seems to have acted as a "cutting gate"-the mechanism used by ranchers to divide cattle into separate pens. Put simply, you either love it or you hate it. While the remarkably binary response to The Skeptical Environmentalist may be an extreme example, it certainly is not an isolated one. Indeed, it says a lot about the nature of the environmental debate at the turn of the twenty-first century. ${ }^{15}$ Despite over three decades of modern environmental laws, the proliferation of citizens groups, think tanks, and other organizations concerned with environmental issues, and the maturation of environmental law and policy into distinct fields of study, one still sees basically two warring camps, both politically and ideologically entrenched on opposite ends of the environmental battlefield. In many respects, the Lomborg conflict is simply the most recent example of this sort of staunch "environmental tribalism."

We are surely not the first to notice the polarization of environmental policy and its scorched earth consequences. For instance, Dan Farber has described the conflict between "tree huggers" and "bean counters" as a fundamental divide over whether environmental law and policy should be determined by "willingness to vote" or "willingness to pay." 16 Bob Percival and his casebook co-authors have framed the conflict as arising between proponents of "moral outrage" and "cool analysis."17

stood was deeply flawed: exaggeration, prevarications, white lies and even convenient typographical errors had been absorbed unchallenged into the folklore of environmental disaster scenarios."), and Charles T. Rubin, Green No More: The Education of an Environmentalist, WKLY. STANDARD, Dec. 24, 2001 , at 33, 33 ("Lomborg skillfully uncovers the source of the bias toward bad environmental news in the scientific community, environmental interest groups, and the media."), with Thomas Lovejoy, Biodiversity: Dismissing Scientific Progress, SCI. AM., Jan. 2002, at 69, 71 ("Lomborg seems quite ignorant of how environmental science proceeds ...."), Pimm \& Harvey, supra note 7 , at 149 ("Like bad term papers, Lomborg's text relies heavily on secondary sources."), Rennie, supra note 8 , at 61 (noting that "many" scientists spoke to Scientific American and complained of Lomborg's "misrepresentation of their fields," his "incomplete use of the data," and his "misunderstanding of the underlying science"), and Stephen Schneider, Global Warming: Neglecting the Complexities, SCI. AM., Jan. 2002, at 62, 62 ("Lomborg admits, 'I am not myself an expert as regards environmental problems'-truer words are not found in the rest of the book ....").

15. Many of the books cited supra note 3, for instance, triggered binary responses similar to the recent Lomborg brouhaha.

16. DANIEL A. FARBER, ECO-PRAGMATISM 39-42 (1999).

17. Robert V. Percival et al., Environmental Regulation: LaW, SCIENCE, AND POLICY 73 (3d ed. 2000). 
Rob Verchick has described the divide as one of the "philosophies of Feathers and Gold."18 In this issue, Chris Schroeder distinguishes between environmental "priests" and "prophets."19 The downside to such fierce tribal alliances is not simply that they make the field unpleasant for those who try to bridge the divide. Rather, the danger is that actual environmental policy outcomes are often found in the unprincipled mishmash lying on the battlefield after adversarial combat, rather than in measures designed specifically to be pragmatic, pluralistic responses to environmental problems. As J.B. Ruhl, who has argued for the creation of a "radical middle" to break this tribal deadlock, bluntly complains, "I, for one, am not sure that the annihilation process in environmental law will ever come to an end as long as it is framed by two opposing philosophies and a vacuum in the middle and, frankly, I am sick of it."20

Well, we are too. But we wonder whether environmental tribalism can be replaced by a "radical middle" or "ecopragmatic" approach simply because it makes so much sense to do so. Put another way, while the apt categories listed above of bean counters, priests, feathers, and outrage are surely accurate descriptions of the poles of environmental advocacy, they don't strike us as a broader explanation for the bipolar dynamic. What interests us, therefore, is why the environmental field so often seems to operate as a cutting gate, why it creates such fertile terrain for tribal behavior, and how it can be broadened to include other voices. Without understanding the factors driving the environmental cutting gate, it is difficult to assess whether eco-pragmatic proposals can succeed in environmental policy making simply on the strength of their own merits.

In this regard, consider how environmental protection differs from other strongly divisive public issues. It is, of course, not unusual to have strong advocacy at both ends of a contested issue. Look at the public debates over abortion, the

18. Robert R. M. Verchick, Feathers or Gold? A Civic Economics for Environmental Law, 25 HARV. ENVTL. L. REV. 95, 96 (2001).

19. Christopher H. Schroeder, Prophets, Priests, and Pragmatists, 87 MinN. L. REV. 1065, 1065-77 (2003).

20. J.B. Ruhl, Working Both (Positivist) Ends Toward a New (Pragmatist) Middle in Environmental Law, 68 GEO. WASH. L. REV. 522, 524 (2000) [hereinafter Pragmatist Middle]; see also J.B. Ruhl, A Manifesto for the Radical Middle, 38 IDAHO L. REV. 385, 385-86 (2002) Thereinafter Radical Middle]. 
death penalty, or gun control-such fields also seem dominated by loud "pro" and "anti" voices. But let's look more closely at the abortion debate, which on its face seems pretty similar. It is certainly hard to find a more "theological" topic that pits differing worldviews against each other. As a useful comparison to environmental disputes where feelings run high (such as drilling for oil in the Arctic National Wildlife Refuge ${ }^{21}$ ), so far so good. Notice, however, the interesting difference that in the abortion field, the general public is also polarized, with feelings running strongly either that abortion is tantamount to murder or that (up to a certain stage) it is simply a medical treatment within the discretion of the mother. ${ }^{22}$ In the environmental field, by contrast, most of the public is not similarly polarized. In fact, polls show a consistently high level of support for environmental protection, ${ }^{23}$ and that is what makes the cutting gate phenomenon in environmental law and policy so surprising.

On the topic of abortion, the advocacy dynamic seems to mirror broader public perceptions. On the environment, however, that does not seem to be the case, as political advocacy by bean counter and tree hugger tribes alike seems more extreme and more polarized than the public constituencies these groups claim to represent. More interesting still, the groups that could claim to speak for this great silent majority cannot seem to make it on the political stage. Thus, we have a growing number of leading

21. See infra text accompanying note 59 .

22. See Lydia Saad, Public Opinion About Abortion-An In-Depth Review, at http://www.gallup.com/poll/specialReports/pollSummaries/sr02012

2.asp (last visited Mar. 3, 2003) (reporting the results of an August 2001 Gallup survey in which $46 \%$ of respondents considered themselves to be prochoice, while $46 \%$ called themselves pro-life, and reporting the results of May 2001 Gallup survey in which $42 \%$ of respondents stated that abortion is morally acceptable, while $45 \%$ felt that it is morally wrong).

23. Chris Schroeder has gathered an extensive array of opinion poll data supporting the assertion that "Americans from every demographic, socioeconomic, racial, and ethnic category identify themselves as concerned about the environment...." Christopher H. Schroeder, Clear Consensus, Ambiguous Commitment, 98 MiCH. L. REV. 1876, 1876, 1896-1906 (2000). As the title of his review indicates, however, Schroeder also notes that the ultimate strength of public environmental commitment "is ambiguous because Americans have not thoroughly considered how they would trade competing values with environmental values in hard cases." Id. at 1905. In Part II infra, we argue that such hard case decisions do not receive public attention and deliberation largely because bean counters and tree huggers fail to frame environmental issues in ways conducive to frank democratic discussion. 
environmental law and policy scholars calling for a pragmatic, centrist approach. ${ }^{24}$ We have a public that seems to widely support just such an approach. ${ }^{25}$ Yet environmental advocacy seems to remain largely a tribal battleground. Why is that? And, more germane to this Symposium, what does that mean for the prospects of an eco-pragmatic approach successfully passing through the cutting gate?

Our exploration of these issues proceeds in two parts. In Part I, we describe in more detail what we mean by environmental tribalism, focusing on reactions to The Skeptical Environmentalist as an illustrative example. Part II then examines the dynamics that drive the cutting gate phenomenon and reinforce tribal behavior. We conclude by noting that the social dynamics described in Part II tend to block both the emergence and acceptance of eco-pragmatism at the level of public advocacy. We argue, therefore, that scholars and others seeking to advance the cause of the "radical middle" should focus their efforts in those areas where environmental tribalism is least entrenched and pragmatism most appreciated-at the level of policy implementation.

\section{TRIBALISM IN ENVIRONMENTAL LAW AND POLICY}

What would an anthropologist make of the furor surrounding The Skeptical Environmentalist? Our sense is that she might describe the two groups of critics and champions (whether labeling them as tree huggers, priests, or some other clever moniker) as operating effectively like modern-day tribes. ${ }^{26}$ It seems clear that those in the environmental policy

24. See, e.g., FARBER, supra note 16, at 9; Radical Middle, supra note 20, at 387; Pragmatist Middle, supra note 20, at 545-46. While the proposals of Farber and Ruhl have significant differences, their main insight is similar-a balanced environmental policy should result from considered deliberation rather than ad hoc compromise. See also SIDNEY A. SHAPIRO \& ROBERT L. GLICKSMAN, RISK REgULATION AT RISK: RESTORING A PRAGMATIC APPROACH (2003).

25. See infra text accompanying notes 101-03.

26. Zyg Plater made a similar observation about environmental advocacy in a 1990 article examining the role of local groups in resource management conflicts through case studies of the Exxon Valdez, old growth logging, and the snail darter. See Zygmunt Plater, A Modern Political Tribalism in Natural Resources Management, 11 PUB. LAND L. REV. 1, 6-17 (1990). He described tribalism as "a cohesive instinctive affiliation between people based on their recognition of and loyalty to common roots, a narrowed, non-official, racial, social and cultural allegiance that has evolved to have remarkable staying power and utility." Id. at 5. Correspondingly, though, he noted that tribalism 
field already think about themselves and their opponents in tribal terms. Just look at the debate over The Skeptical Environmentalist. In the introduction to his book, Lomborg describes himself as an "old left-wing Greenpeace member" who had unthinkingly bought into the "Litany." 27 While Lomborg apparently includes this self-description to explain how he became interested in the book project, it is fascinating that his former association with Greenpeace has featured so prominently in both the praise and condemnation surrounding the book. A Lexis search turned up no less than 154 stories from around the globe that noted Lomborg's association with Greenpeace, including prominent mass media sources like Time, international publications like The Australian and The Times of London, and more obscure outlets like Fertilizer International. Across the spectrum, commentators seemed keenly interested in the nature of Lomborg's relationship to the Greenpeace organization, which is, after all, one of the most prominent clans of the tree hugger tribe. Indeed, Cambridge University Press noted Lomborg's membership in Greenpeace prominently in its publicity and, recognizing the value of a turncoat, many adulatory reviews have presented his former affiliation as proof of his credentials. The American Enterprise Institute (AEI), a conservative think tank, went so far as to call Lomborg "a wonderful witness for the prosecution." 28 Interestingly, Lomborg's affiliation with Greenpeace came up in many negative reviews as well, with Lomborg attacked as not "really" a member of Greenpeace either because he only paid dues or because he was not an activist. ${ }^{29}$

Why do both sides care so much about whether or not Lomborg "really" belonged to a mass membership organization like Greenpeace years before he wrote the book? A likely

entails exclusion and distrust of non-tribe members: "[P] eople who are not of the tribe can be precluded from consideration, are not owed the same deference as human beings who are members of the tribe; they are in some sense 'alien,' and their interests are excluded from recognition in the process of governance." Id.

27. LOMBORG, supra note 1 , at xix.

28. Glassman, supra note 7, at 16 .

29. See, e.g., Earthbeat, Skeptical Environmentalist Debates Critics, at http://www.abc.net.au/rn/science/earth/stories/s394496.htm (Oct. 13, 2001) (quoting Tom Burke as saying that he "actually talked to Greenpeace, and they are very clear that they have no record of Bjorn Lomborg ... as an activist member," and that "he may have contributed money to Greenpeace ... but ... before you call yourself an environmentalist you have to do a little bit more than contribute money"). 
reason, it seems to us, is that membership in Greenpeace serves as a badge of tribal affiliation. To defenders of Lomborg, not only has he worn the other tribe's colors but, more important, he now denounces their creed. They seem to be thinking that, when it comes to matters of environmental importance, Lomborg should know since, after all, he was once "one of them." 30 To critics of Lomborg, on the other hand, he never really was part of the tribe in the first place, perhaps writing a membership check but not adequately participating in the requisite initiation rites. He therefore cannot speak for the tribe because he never truly belonged. Are we taking the tribal metaphor too far? Perhaps, but how else can one explain the fixation on Lomborg's relationship with Greenpeace-a matter wholly unrelated to the merits of his argument-if not as an attempt on both sides to identify which tribe he belongs to (and therefore can speak on behalf of)?

The tribal dynamic goes beyond mere membership in an exclusive group. As discussed in more detail in the sections that follow, tribal affiliation is also expressed through the sharing of a common worldview (what in a religious context we might call a dogma or orthodoxy). Most of Lomborg's critics, we expect, would support the notion that the earth's environment has a finite carrying capacity and that there are biophysical limits to growth that in a number of cases we are approaching or have exceeded. ${ }^{31}$ Many of Lomborg's supporters, on the flip side, likely view the world through the perspective of resource economics, confident in the belief that any particular resource constraint can be circumvented through market mechanisms and that human ingenuity is the greatest resource of all..$^{32}$

In addition to common shared assumptions, tribal advocacy also reveals itself through a ready acceptance of conclusions based on perceived tribal membership of a speaker and,

30. Similar examples of misguided pasts might include, "Pacifist Joins the Marines" or "Vegetarian Becomes Big Mac Lover."

31. See, e.g., John P. Holdren, Energy: Asking the Wrong Question, SCI. AM., Jan. 2002, at 65, 65 ("What environmentalists mainly say on [the topic of resource scarcity] is not that we are running out of energy, but that we are running out of environment ... running out of the capacity of the air, water, soil and biota to absorb, without intolerable consequences for human wellbeing, the effects of energy extraction, transport, transformation and use.").

32. See, e.g., Kozinski, supra note 6, at 1752-53 (arguing that advances in technology, the ability to substitute resource inputs, and efficiency gains in the use of resources mean that, in the long run, "prices for materials always drop"). 
relatedly, a strong reluctance to admit shortcomings in fellow tribe members' work. These aspects of the environmental movement have been pointed out in a newsletter of the AEI that described the worldview of environmental groups as an "uncompromising viewpoint" that "gives rise to what might be called environmental correctness .... Disagreement with that viewpoint is ascribed to a moral defect." ${ }^{33}$ However accurately this description may fit parts of the tree hugger tribe, it is interesting to note that the AEI authors do not appear to see the same dynamics happening among bean counters as well.

A further feature of environmental tribalism takes the form of a strong skepticism among people who employ the methodologies or languages of competing tribes. This is evident in the educational training and professional affiliations of Lomborg's supporters and critics. In looking at the background of book review authors, with rare exceptions, Lomborg's critics all have been scientists and professional staff members of environmental organizations. Their strongest consistent criticism has been Lomborg's lack of scientific understanding, as demonstrated by his lack of scientific credentials and the fact that he has never published in an academic journal on environmental issues. Lomborg supporters, on the other hand, have largely been social scientists (primarily, economists and political scientists), and they have praised Lomborg for his focus on hard numbers and technical assessment of the costs and benefits of environmental regulation. ${ }^{34}$ It is evident from reading even a handful of these reviews that neither group particularly trusts the other's methodologies, assumptions, or intentions.

While comparing environmental advocacy to a tribal dynamic is, we believe, a useful means for describing the seemingly unbridgeable divide across environmental policy, there are at least three important caveats to keep in mind. First, there is an important distinction between tribal identification and the more common phenomenon of interest group identification. One can point to many advocacy groups that share a political goal but do not necessarily share tribal characteristics. Coming together in a common political cause, such as advocating for a higher minimum wage, frequently

33. Steven F. Hayward \& Christopher DeMuth, AEI's Environmental Policy Outlook, at http://www.aei.org/epo/epo14224.htm (July 2002).

34. Some representative sources on both sides of the Lomborg debate are gathered supra note 14 . 
occurs without producing the same social dynamics that one observes in the environmental field. Something different seems to be at work here. Second, we are by no means suggesting that people in the environmental field are unthinking acolytes who fervently bow at the altar and mouth their tribe's dogma. Yes, Virginia, we do have free will. Those within the environmentalist community often differ on specific issues, as do those who fall within the bean counter tribe. Nevertheless, despite these individual variations, social forces clearly are at work within the field that tend to reproduce tribal behavior time after time and, importantly, that seem also to impede the development of more integrated, inclusive advocacy. Third, while the tribalism phenomenon creates an impression that environmental protection is divisive and polarized throughout the field, a middle does exist, of course, between the two poles of the environmental spectrum. As we discuss at the end of this Article, ${ }^{35}$ this is most evident at the policy implementation level, where compromise happens quite often and might even be described as the way of the world. Our initial focus, however, is at the public advocacy level. It is here, we contend, that the cutting gate continues to operate and that the level of discourse has long remained bipolar.

\section{THE CUTTING GATE}

While modern environmental law may have been ushered into existence by "an orgy of consensus," 36 its recent public visage more closely resembles a stockyard. Just as cattle are deftly herded into separate pens by a cutting gate, participants in environmental law and policy debates often seem to respond to a cutting gate of their own, a set of values, beliefs, or characteristics that divide them neatly into pens of "bean counters" and "tree huggers," to use Farber's evocative distinction. Occasionally, some salient event like the release of The Skeptical Environmentalist shines an especially bright light on these pens, exposing both the deep divisions within the environmental law and policy community and the mudslinging, caterwauling, grunting, and groaning that exist between them. What is not so clearly revealed, however, are the dynamics that drive the cutting gate phenomenon in the first place. Only by better understanding the forces that drive environmental

35. See infra text accompanying notes 119-23.

36. Radical Middle, supra note 20, at 388. 
advocates farther apart can one identify where eco-pragmatic approaches will be most likely to succeed. The following sections explore this issue by reviewing a variety of explanations, both old and new, for the cutting gate phenomenon (many of which were noted by Farber in his keynote presentation to this Symposium). ${ }^{37}$

\section{A. AdVERSARIAl Policy MaKing}

A common explanation for the cutting gate is the fact that environmental policy tends to be formed within highly contested, adversarial settings. Under such conditions, extremism is a strategically effective form of advocacy and, indeed, may even be necessary to end up with an acceptable middle compromise. As John Dwyer notes, "[T]he posturing that accompanies adversary proceedings polarizes the debate, making accommodation less likely. Parties may take extreme positions to satisfy constituencies or ideological commitments. As substantive positions harden, parties may find it more difficult to make tradeoffs. The inevitable result is more litigation and delayed policymaking." 38 Thus, even if competing environmental tribes agree on the state of relevant scientific knowledge and agree on the consequences of adopting or delaying regulation, the rule-making process still may tend to appear dramatically polarized because neither tribe will be willing to weaken its bargaining position by conceding ground $a b$ initio. ${ }^{39}$ Put simply, ugly though it may be, tribalism works. ${ }^{40}$

37. See Daniel A. Farber, Building Bridges Over Troubled Waters: Ecopragmatism and the Environmental Prospect, 87 MINN. L. REV. 851, 861 (2003) (describing barriers to effective environmental decision making posed by "the limited ability of voters to process information about environmental issues," and "distortions in public discourse and in the legislative process").

38. See John P. Dwyer, Contentiousness and Cooperation in Environmental Regulation, 35 AM. J. COMP. L. 809, 820 (1987) (citations omitted).

39. This strategic positioning is, of course, even more apparent in public advocacy fora such as radio talk shows, newsmagazines, and other popular media outlets. See infra text accompanying notes 71-77.

40. As detailed in infra text accompanying notes 119-23, concerted efforts have been made by both academics and regulators to fashion less adversarial approaches to environmental rule making that may reduce tribal posturing. At present such reinvention remains fairly atypical within environmental regulation. See Richard B. Stewart, A New Generation of Environmental Regulation?, 29 CAP. U. L. REV. 21, 23-25 (2001). Nevertheless, Farber believes that new models of the regulatory process will garner increasing 


\section{B. COMPETING WorLdVIEWS}

Another frequent explanation for polarity among environmental advocates points to a stark, irreconcilable contrast in worldviews. Farber, for instance, argues that "[c]ontesting [d]ogmas"41 lie at the heart of environmental polarization: one in which the natural sphere is viewed as intrinsically valuable and worthy of protection irrespective of its instrumental significance versus another in which the environment is seen as a material resource that should be subjected to market dynamics like any other input to production. The former tree hugger vision emphasizes the need for public participation in environmental, health, and safety decision making in order to ensure that the sacredness of life and nature are given effect in public policy. The latter bean counter vision argues that such decision making should be determined primarily, if not solely, by weighing the costs and benefits at stake, where costs and benefits are measured by market-expressed preferences or their nearest equivalent. ${ }^{42}$ As many scholars have argued, if these competing normative orientations accurately describe most advocates' viewpoints in environmental policy debates, then meaningful dialogue or compromise among them will be essentially precluded. ${ }^{43}$

support as the necessity of workable, compromise solutions to environmental problems becomes ever more apparent: "So long as the political equilibrium requires accommodation between supporters and opponents of environmental regulation, rather than allowing a clear-cut victory to one side or the other, reinvention will be a politically attractive platform." Daniel A. Farber, Triangulating the Future of Reinvention: Three Emerging Models of Environmental Protection, 2000 U. ILL. L. REV. 61, 67-68.

41. FARBER, supra note 16 , at 5 .

42. See id. at 39 ('[T]he choice seems to lie between 'tree huggers,' who hold the environment sacred and reject economic values as profane, and 'bean counters,' who believe only in values that can be quantified in dollars and cents.").

43. To complicate matters further, libertarianism provides an additional competing worldview in the environmental context that plays a strong role in land use policy, takings, and other areas related to property rights. Specifically, opponents of environmental restrictions on property use tend to view governmental regulation as an unjustified infringement on private liberty. See Farber, supra note 37 , at 862 (describing the "counterreformationists who are less interested in tradeoffs between costs and benefits than in using the Constitution to eviscerate environmental regulation"); Keith Hirokawa, Some Pragmatic Observations About Radical Critique in Environmental Law, 21 STAN. ENVTL. L.J. 225, 233 (2002) (noting that opposition to the Endangered Species Act "has consistently cited the protections of property rights deeply established in constitutional, statutory and common law"); Richard Epstein, Too Pragmatic by Half, 109 YALE L.J. 
Discussants may appear to address the same subject matter, but they will do so by employing conceptual categorizations that simply do not translate into each other's terms. ${ }^{44}$ As the title of a 2002 Symposium held at the University of Florida stated so well, "Industry is from Mars, Environmentalists are from Venus." 45

We have little doubt that the rhetorical surface of environmental advocacy often reflects these competing worldviews. ${ }^{46}$ However accurate, though, this description does not account for why one is guided into the tree hugger or bean counter pen in the first place. ${ }^{47}$ After all, bean counters do not prefer cost-benefit analysis out of unprincipled contempt for public judgment. Rather, they argue against purely democratic resolution of environmental, health, and safety regulation issues by citing problems of rent-seeking at the political level and the public's frequent lack of adequate knowledge to make welfare-maximizing decisions at the grassroots level. Even when accurate scientific information is available to the public, bean counters point out that lay judgments still often rely on cognitive heuristics that lead to normatively undesirable

1639, 1642 (2000) (reviewing FARBER, supra note 16) (describing viewpoint of those "who see in the self-professed environmental movement an arrogance that results in the trampling of individual liberty"). In keeping with Farber's typological theme, we might refer to these property rights advocates as "fence builders."

44. Cf. MARK Sagoff, The ECONOMY of the EARTH: Philosophy, LAW, AND THE ENVIRONMENT 94 (1988) (arguing that analysts who rely on willingness-to-pay measures of environmental protection commit a "category mistake": They "ask[] of beliefs about objective facts a question that is appropriate only to subjective interests and desires").

45. See Symposium, Industry is from Mars, Environmentalists are from Venus: Reconciling our Differences on Earth, 17 J. LAND USE \& ENVTL. L. 375 (2002).

46. Witness, for instance, the strong reaction provoked by the efforts of leading environmental scientists to provide monetary estimates of the instrumental value of ecosystem services to humanity. See, e.g., GRETCHEN C. DAILY \& KaTHERINE Ellison, THE NEW ECONOMY OF NATURE: THE QUEST TO MAKE CONSERVATION PROFITABLE 1-17 (2002). Rutgers University biologist David Ehrenfeld provides a representative, if charged, example of this reaction: "I am afraid that I don't see much hope for a civilization so stupid that it demands a quantitative estimate of the value of its own umbilical cord." Jeff Gersh, Bigger, Badder-But Not Better, THE AMICUS J., Jan. 1, 1999, at 32, 36.

47. We realize, of course, that dividing the environmental advocacy world into tribes of bean counters and tree huggers is overly simplistic. While there will surely be some counter examples to many of the generalizations we make in this Article, we believe that the cutting gate phenomenon is real and strongly operates in a bipolar fashion. 
results when dealing with complex risk tradeoffs. Most individuals, for instance, seem to respond to the mere possibility of certain types of risk, such as the meltdown of a nuclear reactor, rather than the probability of such an event. ${ }^{48}$ In that case, lay demand for safety in the nuclear industry may be insensitive to the magnitude of risk or the diminishing marginal utility of increased safety investment-attitudes that strike bean counters as being inconsistent with widely accepted notions of rationality. ${ }^{49}$ Similarly, individuals tend to exhibit different regulatory preferences when previously unnoticed costs and benefits of action are forced "on-screen," yet few aspects of the individual's everyday information environment direct attention to such "off-screen" factors. ${ }^{50}$

Accordingly, bean counters believe that public demand for environmental, health, and safety regulation may not reflect truly informed preferences. Advocates of risk-risk analysis, comparative risk assessment, and allied decision-making tools aim to overcome informational and cognitive limitations of this sort by institutionalizing procedures for unearthing opportunity costs, unintended consequences, and other matters likely to fall into regulatory blind spots. As these examples make clear, bean counters advocate technocratic approaches to risk regulation such as cost-benefit analysis, not to supplant public judgment, but rather to provide the public with the level of environmental, health, and safety investment that it hypothetically would demand given better scientific information and a decision-making context that permits dispassionate analysis. ${ }^{51}$ Lomborg's tome, flawed though it

48. See Paul Slovic et al., The Affect Heuristic, in HEURISTICS AND BIASES: THE PSYCHOLOGY OF INTUITIVE JUDGMENT 397, 397-400 (Thomas Gilovich et al. eds., 2002).

49. See FARBER, supra note 16, at 66 ("Surely, we don't want government policy to be based on irrational hysteria about environmental problems."); Cass R. Sunstein, Probability Neglect: Emotions, Worst Cases, and Law, 112 YALE L.J. 61, 106 (2002) (noting that, in general, "the government should not respond if the public is demanding attention to a statistically miniscule risk, and doing so simply because people are visualizing the worst that can happen").

50. See Howard Margolis, Dealing with Risk: Why the Public AND THE EXPERTS DISAGREE ON ENVIRONMENTAL ISSUES 121-43 (1996).

51. See W. KIP VISCUSI, REFORMING PRODUCTS LIABILITY 63 (1991) ("If [the] market ideal was generally applicable, there would be no need for social risk management institutions such as products liability or regulatory agencies."). 
may be, ${ }^{52}$ nevertheless reflects a common belief among observers of the risk regulation process that public understanding of the "Real State of the World" is woefully misinformed and that such misunderstanding leads to suboptimal allocation of public resources..$^{53}$

The competing tree hugger tribe also becomes significantly more nuanced in its worldview upon close inspection. Tree huggers, for instance, do not object to cost-benefit analysis out of Luddite disdain for expert judgment. Rather, they argue that the manner in which cost-benefit analysis is conducted in practice excludes a variety of significant, morally relevant considerations. Reducing risk to a quantitative estimate of harm, for instance, ignores a host of ways in which qualitative dimensions of environmental, health, or safety hazards matter significantly to lay observers. ${ }^{54}$ Failure to account for such dimensions may lead experts to systematically understate the welfare gains to be achieved from hazard avoidance.55 Similarly, when monetizing the benefits of environmental,

52. See generally Douglas A. Kysar, Some Realism About Environmental Skepticism, 29 EcOL. L.Q. (forthcoming 2003) (reviewing LOMBORG, supra note 1).

53. A large and controversial literature, for instance, argues that federal environmental, health, and safety expenditures could be reallocated to produce a greater number of total lives saved. See, e.g., ROBERT W. HAHN ET AL., Do FEDERAL REgUlations REDUCE MORTALITY? 1 (2000); Ralph Keeney, Mortality Risks Induced by Economic Expenditures, 10 RISK ANALYSIS 147, 147 (1990); Randall Lutter \& John F. Morrall III, Health-Health Analysis: A New Way to Evaluate Health and Safety Regulation, 8 J. RISK \& UNCERTAINTY 43, 49 tbl.1 (1994); Tammy O. Tengs \& John D. Graham, The Opportunity Costs of Haphazard Social Investments in Life-Saving, in RISKS, COSTS, AND LIVES SAVED: GETTING BETTER RESULTS FROM REGULATION 167, 167 (Robert W. Hahn ed., 1996); W. Kip Viscusi \& Richard J. Zeckhauser, The Fatality and Injury Costs of Expenditures, 8 J. RISK \& UNCERTAINTY 19, 19 (1994); W. Kip Viscusi, Mortality Effects of Regulatory Costs and Policy Evaluation Criteria, 25 RAND J. ECON. 94, 94 (1994).

54. See Clayton P. Gillette \& James E. Krier, Risks, Courts, and Agencies, 138 U. PA. L. REV. 1027, 1075 (1990) (reviewing evidence suggesting that "[f]or lay people, 'riskiness' means more than 'expected number of fatalities"' and that "[f]or experts, it doesn't" (citation omitted)); Paul Slovic, Perception of Risk, in THE PERCEPTION OF RISK 220, 231 (Paul Slovic ed., 2001) (noting that lay individuals' "basic conceptualization of risk is much richer than that of experts and reflects legitimate concerns that are typically omitted from expert risk assessments").

55. See Gillette \& Krier, supra note 54, at 1075 ("[E]xpert assessments of the high-technology hazards so prominent in the public risk debate will commonly be understated when viewed from the popular perspective, because lay assessments work up from the point at which experts tend to stopexpected mortality and morbidity." (footnote omitted)). 
health, and safety regulation, practitioners of cost-benefit analysis tend to rely on market-derived data that are intended to capture the public's "revealed preference" for preserving human life or natural goods. Tree huggers object that individuals do not ordinarily conceive of such items in commodity terms and therefore may not provide particularly meaningful valuations for policy analysis through their market behavior. Finally, the bean counters' practice of discounting the future benefits of regulation to a present value also suffers from a conceptual problem in the view of tree huggers. Many aspects of environmental decision making entail judgments regarding the distribution of natural resources between generations-judgments that arguably should precede the use of a discount rate, not be determined by it. ${ }^{56}$ Thus, tree huggers favor public resolution of risk regulation issues, not to ignore scientific and technical methodologies, but to provide an outlet for expression of values that they do not believe can be subsumed within such methodologies.

In short, although many commentators argue that bean counters and tree huggers share only "a belief that environmental policy can be based on a single overriding value, whether that value is economic or environmental," 57 such extremism characterizes the rhetoric more than the reality of their viewpoints. Like the public at large, bean counters and tree huggers instead seem to recognize the existence of competing economic and environmental considerations. In practical terms, their differences ultimately reduce to contrasting beliefs over the proper manner to weigh and compare such values, not a dispute concerning their existence or their political validity. Bean counters tend to favor technocratic resolution of risk regulation issues because they believe that "willingness to. vote" carries with it informational

56. See Daniel A. Farber \& Paul A. Hemmersbaugh, The Shadow of the Future: Discount Rates, Later Generations, and the Environment, 46 VAND. L. REv. 267, 289-93 (1993); Lisa Heinzerling, Discounting Life, 108 YALE L.J. 1911, 1915 (1999); Lisa Heinzerling, Discounting Our Future, 34 LAND \& WATER L. REV. 39, 40-41 (1999); Lisa Heinzerling, Environmental Law and the Present Future, 87 GEO. L.J. 2025, 2069 (1999); Richard B. Norgaard \& Richard B. Howarth, Sustainability and Discounting the Future, in ECOLOGICAL ECONOMICS: THE SCIENCE AND MANAGEMENT OF SUSTAINABILITY 88, 97-98 (Robert Costanza ed., 1991); Richard L. Revesz, Environmental Regulation, Cost-Benefit Analysis, and the Discounting of Human Lives, 99 COLUM. L. REV. 941, 947-48 (1999).

57. See FARBER, supra note 16, at 9. 
and cognitive deficiencies that result in suboptimal allocation of society's limited resources. Tree huggers tend to favor democratic resolution of the same issues because they believe "willingness to pay" imperfectly captures the value that society derives from investing in the environment. Both tribes seem to agree, though, that the regulatory goal consists in maximizing the benefit-broadly construed-that society derives from its natural capital. ${ }^{58}$ This account, then, tells a more hopeful story than the standard competing worldviews account of environmental polarization, where bean counters and tree huggers speak past each other, their arguments passing like ships in the night. Perhaps, instead, the divide is less theological than commonly assumed, with space for common pragmatic agreement. As the next section describes, however, strong social and cognitive dynamics frustrate environmental consensus building.

58. See Schroeder, supra note 19 , at 1070 (noting that the instrumentalist "vernacular of the priesthood has gained an upper hand as the language used in the policy debates"); A. Dan Tarlock, Slouching Toward Eden: The Ecopragmatic Challenges of Ecosystem Revival, 87 MINN. L. REV. 1173, 1178 (2003) (noting that the anthropocentric view of environmental law generally has prevailed and that "[e]nvironmentalism has become a more rational movement, dominated by economics and ecology," rather than morality and spirituality). There are important exceptions, of course. The Endangered Species Act, for instance, is often justified by the moral maxim that human activity should not cause the complete erasure of nonhuman life. See Tenn. Valley Auth. v. Hill, 437 U.S. 153, 173-88 (1978) (reviewing the history and purpose of the Endangered Species Act). Conversely, opposition to the Endangered Species Act, wetlands regulation, and other environmentally justified impositions on land use typically invokes the language of individual rights, rather than that of consequentialist reasoning. See supra note 43. Increasingly, though, even these debates are adopting an instrumentalist vernacular. Recent defenses of species preservation, for instance, have focused on the potential significance of biodiversity as an indicator of or even determining factor of ecosystem service provision: "Although the relationship between biodiversity and ecosystem processes is complex, researchers are repeatedly finding that diversity of species assemblages is tied directly to ecosystem productivity, resilience, and sustainability." Pragmatist Middle, supra note 20 , at $542-43$. Similarly, the property rights movement seems to have become attracted to the ideas provided by free market environmentalism, in which property rights are seen as desirable not merely as means of effectuating individual liberty, but also as instruments for grappling with certain forms of environmental externalities. See, e.g., James L. Huffman, Judge Plager's "Sea Change" in Regulatory Takings Law, 6 FORDHAM ENVTL. L.J. 597, 598 n.11 (1995) ("Advocates of free market environmentalism take the position that property rights protection is critical to wise resource management and that many, if not most, environmental objectives will be better achieved through a clearly defined system of property rights and free markets."). 


\section{THE ROLE OF KNOWLEDGE}

Different worldviews suggest not only a values divide but, equally important, different perceptions of relevant knowledge regarding human development, environmental impact, and the demand for environmental, health, and safety regulation. As a result, environmental advocacy rarely focuses solely, or even primarily, on ethics. Instead, given the inevitable uncertainty surrounding environmental policy decisions, advocacy debates typically consist of competing accounts of the likelihood and severity of a threatened environmental harm or the cost and effectiveness of a proposed regulatory initiative. Just look at the debate over oil drilling in the Arctic National Wildlife Refuge. To be sure, opponents imply that drilling is unethical by calling the Refuge a "pristine wilderness" and "America's Serengeti," but such appeals represent only a small part of the public debate. The key points of contention are empiricalwhat is the likely impact of drilling on local flora and fauna, how much oil will be recovered, and what are the economic benefits to the region? ${ }^{59}$

It is no coincidence, moreover, that the annual publications of environmental organizations typically bear authoritative sounding titles such as the "State of the World" or "Vital Signs." 60 Nor is it a coincidence that Lomborg subtitled his

59. See Sheila Weigert, Note, Arctic National Wildlife Refuge: In the Debate Over Drilling in the Refuge's Coastal Plain, The Environment Is the Only True Loser, 8 ENVTL. LAW. 169, 170-74 (2001) (reviewing a variety of arguments offered for and against drilling in the Arctic National Wildlife Refuge, all of which focus on ecological and economic impacts).

60. Each year, the Worldwatch Institute, an environmental think tank, publishes two factual compendiums entitled "State of the World" and "Vital Signs: The Trends that Are Shaping Our Future." See, e.g., WORLDWATCH INST., STATE OF THE WORLD 2002 (2002); WORLDWATCH INST., VITAL SIGNS 2002: THE TRENDS THAT ARE SHAPING OUR FUTURE (2002). The Competitive Enterprise Institute similarly has published volumes entitled "The True State of the Planet" and "Earth Report 2000: Revisiting the True State of the Planet." See, e.g., COMPETITIVE ENTER. INST., EARTH REPORT 2000: REvisiting THE TRUe State of THE Planet (Ronald Bailey ed., 2000); Competitive Enter. Inst., The True State of the Planet: Ten of tHE WORLD'S PREMIER ENVIRONMENTAL RESEARCHERS IN A MAJOR CHALlENGE TO THE ENVIRONMENTAL MOVEMENT (Ronald Bailey ed., 1995). The World Resources Institute maintains a continuously updated compendium of global environmental, social, and economic data on its website "Earth Trends: The Environmental Information Portal." See World Res. Inst., Earth Trends: The Environmental Information Portal, at http://www.earthtrends.wri.org (last visited Mar. 3, 2003). 
manuscript, "Measuring the Real State of the World."61 Tree huggers and bean counters alike are attempting to position their interpretations of the environmental condition as objective, fact driven, and scientifically grounded. Indeed, it is precisely Lomborg's claim to have captured the import of scientific and economic data free from bias that has incited his critics and emboldened his champions. ${ }^{62}$

This strong emphasis on factual disputes raises the possibility that tribalism is not a permanent or unavoidable feature of environmental policy making. Unlike other policy debates that also seem to reflect fundamentally incompatible worldviews-such as debates over abortion or the death penalty-the environmental debate generally takes place in the context of questions requiring empirical investigation. Thus environmental advocates tend to focus their efforts on convincing the public that their empirical account is the most accurate one. In this regard, the environmental debate seems unique. We have little reason, for instance, to think that complete factual agreement on the deterrent effect of capital punishment or the physiological stages of pregnancy would eliminate polarization in the death penalty and abortion debates. By contrast, if both bean counter and tree hugger tribes could agree on the substance of and confidence limits surrounding relevant physical and social scientific knowledge, then in theory a significant amount of disagreement over the necessity and desirability of environmental regulation would disappear. Indeed some observers of environmental law are optimistic that the era of polarization eventually will greatly diminish, if not come to an end. Dan Esty, for instance, argues that

[b]y reducing the scope of what is 'art' (as opposed to science) in environmental debates, we will be able to narrow the range over which political judgment must be exercised. In doing so, we will reduce the depth of the current political divide that makes today's environmental politics so polarized. ${ }^{63}$

We share the hope that advances in knowledge will help catalyze meaningful dialogue among participants in policy-

61. See LOMBORG, supra note 1.

62. In this regard, witness the remarkable frequency with which Lomborg's positive reviewers mention the number of footnotes contained in The Skeptical Environmentalist, as if prolific footnoting were a reliable indicator of scientific veracity. See Kysar, supra note 52 (manuscript at 3).

63. Daniel C. Esty, Next Generation Environmental Law: A Response to Richard Stewart, 29 CAP. U. L. REV. 183, 200 (2001) (footnote omitted). 
making debates. Notably, recent examples of environmental success stories such as the Montreal Protocol's CFC phase-out seem driven in large part by the international environmental policy-making community's widespread agreement on the underlying scientific facts. ${ }^{64}$ The Intergovernmental Panel on Climate Change (IPCC) provides a similar case in progress, with (almost all) national governments stating that their policy positions will be driven in part by the findings of this international body of scientists. ${ }^{65}$ Conceivably, if similar consensus were achieved on the scope and content of knowledge regarding other environmental issues, then the calculus of environmental, health, and safety decision making would become considerably less polarized and more tractable.

As the following sections explain, however, there are reasons to remain circumspect about the possibility of fact driven consensus in environmental law and policy. Specifically, a number of social dynamics inherent in environmental advocacy seem likely to impede the emergence of an effective,

64. At some point, in other words, the relevant producers of CFCs could no longer plausibly contest the relationship between the gases and ozone depletion. See Michael E. Kraft, Environmental Policy \& Politics 20 (2001) (citing the Montreal Protocol as an example of how "[c]onsensus among scientists can speed agreement on how to respond to hazards"); see also id. at 33 (noting that the CFC phaseout "is often cited as a model of global environmental governance").

65. Even the Bush administration no longer disputes the existence, of human influence on climate change. In 2002, the Environmental Protection Agency issued a report focusing on the threatened impact of climate change to the United States that was very much in line with IPCC scientific predictions. See Envtl. Prot. Agency, U.S. Climate ACTION RePort-2002 (2002). To be sure, President Bush appeared not to embrace the document with zeal: when asked by a reporter to comment on the study, he replied simply, "I read the report put out by the bureaucracy." George Archibald \& Carter Dougherty, Bush Pans Kyoto as Japan OKs Pact; EPA Diverges From President's Views, WASH. TIMES, June 5, 2002, at A1. As a general matter, though, the Bush administration shifted its opposition to the Kyoto Protocol from scientific to economic grounds-that is, from being scientifically unfounded to being excessively costly. See id. (quoting President Bush as saying that "[t]he Kyoto treaty would severely damage the United States economy," and that he "[doesn't] accept that"). As further demonstration of a growing scientific consensus, consider the fact that several major oil companies have now acknowledged the relationship between carbon emissions and climate change (although their concessions come on the heels of a protracted information campaign to the contrary, see infra text accompanying notes 80-83). See Richard L. Ottinger \& Mindy Jayne, Global Climate Change Kyoto Protocol Implementation: Legal Frameworks for Implementing Clean Energy Solutions, 18 PACE ENVTL. L. REV. 19, 70 (2000) (describing movements of oil companies to acknowledge climate change). 
eco-pragmatic constituency on the public stage, regardless of the degree of factual consensus that develops among scientific experts on environmental issues. Tribal rivalry has proven resilient even as our knowledge base becomes ever more complete.

\section{Group Polarization}

As much as knowledge plays a basic role in environmental policy decisions, so too, does uncertainty over knowledge. The debate over climate change, for instance, is plagued by scientific uncertainty over its likely physical and biological impacts as well as economic uncertainty over the costs of such impacts and various proposed mitigation strategies. Because even those environmental issues where knowledge is well developed remain complex, a great deal of interpretive discretion inheres in the comprehension and communication of scientific and economic knowledge regarding environmental issues. Moreover, the combination of uncertainty and complexity creates an atmosphere conducive to group polarization-the tendency for individuals to become more extreme in their views by virtue of their membership in a group. ${ }^{66}$ Thus, rather than being brought closer together by the development of scientific knowledge, environmental groups may in fact become more polarized as the mounting record of evidence gets interpreted in vastly different ways by opposing tribes. This certainly seems to have been the case in the debate over The Skeptical Environmentalist.

Cass Sunstein recently provided an overview of social science research exploring such dynamics. ${ }^{67}$ As he notes, groups tend to become more polarized as they deliberate due to two principal mechanisms. First, and most intuitively, groups face an "argument pool" problem in that their background beliefs may lead them to selectively seek out, offer, and consider evidence and arguments that are skewed to support their pre-deliberative tendencies (i.e., to believe that the state of the environment is either degrading or improving). If, in the extreme, environmental doomsayers only read and discuss reports published by Greenpeace, and if environmental naysayers only read and discuss the optimistic accounts of

66. See Cass R. Sunstein, Deliberative Trouble? Why Groups Go to Extremes, 110 YALE L.J. 71, 74 (2000).

67. See id. at 77-96. 
authors such as Lomborg, then both groups are likely to become more entrenched in their views by virtue of group affiliation. ${ }^{68}$ In fact, it is more subtle than this, since both groups can read a careful report with ranges of impacts, such as those from the IPCC, and then consciously or unconsciously select only the low or high ends of the range with little or no attention to relevant measures of likelihood. ${ }^{69}$

Second, members of groups tend to become more extreme in their pre-deliberative views because of social influences on self-perception..$^{70}$ Put simply, if one person's sense of self includes a belief that she is "greener" than the average individual, then her beliefs and choices are dependent to some extent on her concept of the average individual. Thus, associating primarily or exclusively with like-minded individuals may prompt her to become more extreme in her environmental views simply in order to maintain her self-image as being "greener" than average.

A third contributor to group polarization comes from the activity of individuals and entities that seek for one reason or another to raise the salience of certain ideas or beliefs in public discourse. Such "availability entrepreneurs"71 play upon the well-documented cognitive tendency of individuals to confuse salience with prevalence, or vividness with commonness. ${ }^{72}$ By

68. In the extreme case, a tribe becomes so segregated and biased in its deliberative tendencies that it ceases to command any respect whatsoever outside the narrow confines of its membership. The attempt to equate Lomborg and his champions with Holocaust deniers appears to have been intended to attach such a stigma to environmental naysayers. See supra text accompanying note 7 .

69. Stephen Schneider, for example, argues that Lomborg's approach to global climate change in The Skeptical Environmentalist consisted of simply selecting from Intergovernmental Panel on Climate Change reports the least threatening of every range of climate change impacts and the most threatening of every range of mitigation costs. See Schneider, supra note 14, at $62-64$.

70. See Sunstein, supra note 66 , at 88-89.

71. See Timur Kuran \& Cass R. Sunstein, Availability Cascades and Risk Regulation, 51 STAN. L. REV. 683, 683 (1999). In related work, Sunstein also has referred to "polarization entrepreneurs," see Sunstein, supra note 66, at 97, "norm entrepreneurs," see Cass R. Sunstein, Social Norms and Social Roles, 96 COLUM. L. REV. 903, 909 (1996), and "terrorist entrepreneurs," see Cass R. Sunstein, Why They Hate Us: The Role of Social Dynamics, 25 HaRV. J.L. \& PUB. POL'Y 429, 430 (2002).

72. See Jon D. Hanson \& Douglas A. Kysar, Taking Behavioralism Seriously: The Problem of Market Manipulation, 74 N.Y.U. L. REV. 630, 662-64 (1999) (reviewing psychological literature on the availability heuristic). 
highlighting certain dramatic facts, stories, or scenarios, availability entrepreneurs seek to instigate self-reinforcing mechanisms "through which expressed perceptions trigger chains of individual responses that make these perceptions appear increasingly plausible through their rising availability in public discourse."73 In this manner, "mass delusions" may be created that "produce wasteful or even detrimental laws and policies." 74

A similar, though less sophisticated, story has long been told by bean counters in environmental debates. Environmental groups, citizen groups, public health advocates, and other public interest entities have been derided for triggering heightened national concern about the use of certain substances such as chemical pesticides, toxic waste, and uranium-substances that expert risk assessments conclude are less worthy of attention than many less prominent environmental, health, and safety concerns. ${ }^{75}$ Often, critics point to particularly prominent historical events that seem in retrospect to have enflamed such "mass delusions." The Alar, Love Canal, and Three Mile Island controversies frequently are cited by bean counters as examples of the public's tendency both to overreact to hazards and to demand inappropriate legislative or regulatory responses. ${ }^{76}$ In light of these seemingly alarmist episodes, bean counters argue that environmental regulators should be insulated from populist demands for government action and that risk regulation policies should be shielded from the effects of the "junk science" that gives rise to such demands. ${ }^{77}$

73. Kuran \& Sunstein, supra note 71, at 685 .

74. Id.

75. A famous report of perceptions of seriousness of environmental problems found little agreement among public observers and Environmental Protection Agency experts as to the nation's top risk priorities. See Leslie Roberts, Counting on Science at EPA, 249 SCIENCE, 616, 616 (1990). As noted in the text, such disjunctions often are attributed to the advocacy of environmentalists. See, e.g., Kozinski, supra note 6, at 1750 (claiming that "our perceptions are shaped by media reports that uncritically adopt and amplify the predictions of doom peddled by professional environmentalists"); Sunstein, supra note 66, at 98 ("[T] $\mathrm{T}$ he environmental area is filled with leaders who took advantage of cascade-like processes and group polarization.").

76. See Kuran \& Sunstein, supra note 71, at 691-701 (citing the Love Canal and Alar episodes as examples of mass scares).

77. For instance, Kuran and Sunstein argue that risk regulation policies should be reformed to help protect government decision makers from the arbitrary public demand that grows out of availability cascades and the efforts 
Two points are worth noting. First, it is not always, nor perhaps even often, the case that lay-expert divergence in risk attitudes can be attributed to scientific naiveté on the part of the public. ${ }^{78}$ Second, and more important, the "mass delusions" account only attends to half of the contest to manage public perceptions. While certainly not denying the polarizing influence of socially motivated environmental activists, it is important to recognize that other actors who are often found in the bean counter camp (such as industry trade organizations, chambers of commerce, conservative think tanks, business lobbying groups, and other economically-motivated entities) also can manipulate public perception in a manner likely to generate informational biases. ${ }^{79}$ Consider, for instance, the

of availability entrepreneurs. See id. at 746-59. That is, instead of heeding "regulatory demands rooted in availability cascades based on false information," policy makers should provide "a measure of deference to the purely factual judgments of scientific experts." Id. at 737 (footnote omitted).

78. As noted supra text accompanying notes 54-56, some portion of the divergence between lay and expert risk evaluations can often be attributed to the public's "thicker" or "richer" conceptions of risk which include qualitative nuances that may be ignored or underweighted by expert assessments. Additionally, apparent public overestimation of an ecological or human health threat may turn out to be scientifically justified in the long run. Public concern over suspected endocrine disruptors, for instance, is sometimes described as lacking scientific support. See LOMBORG, supra note 1, at 244 (surveying the debate over hormonal activity of synthetic chemicals and concluding that "[o]ur latest chemical fear of pesticides seems surprisingly unfounded"). Yet the only point of agreement among experts regarding the issue seems to be that further research is both needed and warranted. See ENVTL. PROT. AGENCY, ENDOCRINE DISRUPTOR SCREENING PROGRAM: REPORT TO CONGRESS 4 (2000). Thus, dismissing public fears sometimes may overlook the fact that scientific understanding almost unavoidably appears ill-formed during the early stages of investigating a potential hazard.

79. Cf. Lisa Heinzerling, Pragmatists and Environmentalists, 113 HARV. L. REV. 1421, 1439-42 (2000) (reviewing FARBER, supra note 16) (describing the role of industry funded studies in controversy surrounding risks of dioxin). Indeed, given their relative ease of access to media outlets through advertising relationships, their extensive political influence through disproportionate lobbying efforts and campaign contributions, and their greater ability to organize into concentrated, cohesive, and well funded factions during public debate, these actors may be more likely to cause availability cascades than the social activists that lie at the heart of the bean counters' concern. This contention can be supported by analogy from principles of interest group analysis. Public choice theory, which holds that "among the most important sources of real world political failure is the undue influence of well organized private groups as against diffuse, poorly organized majorities," Cass R. Sunstein, Sexual Orientation and the Constitution: A Note on the Relationship Between Due Process and Equal Protection, 55 U. CHI. L. REV. 1161, 1177 n.79 (1988), would seem to apply with equal force to the entrepreneurial solicitation of socially harmful availability cascades. Cf. Farber, supra note 37, at 863 
efforts of fossil fuel and manufacturing industry groups to manipulate public perception of the global climate change problem. Business-funded nongovernmental organizations began to take an active role in global climate change discussion following international recognition of the seriousness of the problem at the 1992 United Nations Conference on Environment and Development in Rio de Janeiro. ${ }^{80}$ Their strategy during the ensuing negotiations has been to fund availability campaigns that create two impressions in the mind of the public: first, that scientists are roughly evenly divided over whether greenhouse gas emissions cause global climate change, ${ }^{81}$ and, second, that economists are unanimous in thinking that global climate change mitigation measures will lead to fiscal disaster. ${ }^{82}$ Both of these contentions are misleading, yet the twin sound bites of industry's massive and

("II]ndustry trade groups are easier to organize than the public at large .... A corollary is that special interests are likely to have a large impact on our ability to enact environmental legislation." (footnote omitted)).

80. Indeed, at more recent international climate change conferences, business-supported nongovernmental organizations have greatly outnumbered their environmentalist counterparts. Chiara Giorgetti, From Rio to Kyoto: $A$ Study of the Involvement of Non-Governmental Organizations in the Negotiations on Climate Change, 7 N.Y.U. ENVTL. L.J. 201, 220 (1999).

81. Hence, the Global Climate Information Project describes global warming as a "naturally occurring phenomenon," and states that projected increases in global temperatures are "likely to decline' as our [scientific] understanding of weather patterns increases." Gwynne W. Guzzeau, Indoor Air Pollution: Energy Problems in China's Residential Sector, 11 GEO. INT'L ENVTL. L. REV. 439, 443 n.41 (1999) (quoting GLOBAL ClIMATE INFORMATION Project, Clearing the AIr ABout THE GREENHOUSE EFFeCT (1997) (on file with Guzzeau)). The Global Climate Coalition likewise "emphasizes the split in the scientific community regarding the 'rate and magnitude' of increased global warming." Id. (quoting Global Climate INFORMATION ProJECT, supra).

82. The Global Climate Coalition, for instance, has funded advertising blitzes that report losses of millions of U.S. jobs and increased prices for such necessities as food and transportation, should the country comply with the Kyoto emissions reduction goals. See Deborah E. Cooper, The Kyoto Protocol and China: Global Warming's Sleeping Giant, 11 GEO. INT'L ENVTL. L. REV. 401, 428 (1999). Meanwhile, the American Petroleum Institute has commissioned economic studies concluding that "emissions reductions amount to unilateral economic disarmament." Id. Such studies receive little serious attention from scholars. Indeed, over 2500 leading economists took the unprecedented step of publishing "The Economists' Statement on Climate Change" which challenged industry claims of financial disaster and asserted instead that emissions reduction policies could be enacted without negative, and perhaps even with positive, consequences for the world's economies. See Douglas A. Kysar, Sustainability, Distribution, and the Macroeconomic Analysis of Law, 43 B.C. L. REV. 1, 39 (2001). 
costly availability campaign appear to have achieved public acceptance: Eighty-four percent of respondents in a recent survey agreed with the statement, "[S]cientists need to do additional research on global warming... before we limit ourselves to what we can or cannot do as an industrialized nation." 83

Thus, economically motivated actors may have a degree of influence over the creation and management of availability cascades that is similar to environmentally motivated actors. This observation is significant because it helps to explain the binary nature of the cutting gate phenomenon in environmental policy making. We do not doubt that environmental advocacy often is pursued through misleading availability campaigns, but we do doubt that the battle unequivocally or uniformly favors Greenpeace. Unfortunately, the nature of scientific information virtually ensures its manipulability in multiple directions. Even where scientific understanding is relatively well developed, risks tend to be stated in ranges, predictions presented with confidence levels, and causal connections drawn with only tentative strokes. Thus, the availability entrepreneur retains ample scope to present scientific claims in a distorted fashion irrespective of whether the scientific community is in agreement regarding the landscape of permissible interpretations. ${ }^{84}$ Importantly, the availability entrepreneur also benefits from a naturally compliant audience: cognitive and social psychology abound with evidence that individuals tend to interpret data, arguments, and perceptions in a manner that reinforces their prior beliefs. ${ }^{85}$ Thus, individuals who think the world is getting better will tend to accept Lomborg's presentation of scientific data, while those who believe the environment is deteriorating will accept the Worldwatch Institute's account. In the process, tribal boundaries will remain strong even as scientific knowledge accumulates.

83. Karlyn Bowman, Revisiting Attitudes About Global Warming As Summer Heats Up, Roll CALL, July 1, 1999, available at 1999 WL 14665886; see also id. (describing Gallup opinion poll results in which "[o]nly 34 percent [of respondents] were worried a great deal about global warming").

84. Cf. supra note 69 (describing Lomborg's selective presentation of data from Intergovernmental Panel on Climate Change reports).

85. See generally Ziva Kunda, Social Cognition: MaKIng SENSE of PEOPLE 211-64 (1999) (discussing factors, such as goals and moods, that affect judgment). 
2. Whose Knowledge?

It also bears noting that environmental policy making must by definition depend on interdisciplinary research in order to make considered judgments regarding the necessity and impact of government regulation. Unfortunately, there is often sharp disagreement among bean counters and tree huggers regarding the proper source of authority for information about environmental threats and the societal impacts of regulatory interventions. ${ }^{86}$ Notable in this regard is the fact that The Skeptical Environmentalist and similar pronouncements of environmental optimism generally come from authors who are not physical scientists, but rather economists, ${ }^{87}$ statisticians, ${ }^{88}$ journalists, ${ }^{89}$ and other authors without formal scientific training. Indeed, critics of The Skeptical Environmentalist were quick to point out that the book was produced and edited by the political sciences division of Cambridge University Press, not its natural sciences division. ${ }^{90}$ Similarly, they note that several prominent reviews of The Skeptical Environmentalist were written by authors who, at first glance, would seem to have little if any expertise to evaluate the strength of Lomborg's scientific claims. The Washington Post, for instance, solicited its review from a New Zealand philosophy professor who was identified, apparently with no trace of irony, as someone "who lectures on the dangers of pseudoscience."91 The Michigan Law Review, in its annual

86. Economist Richard Norgaard observed the following in a review of The Skeptical Environmentalist:

Lomborg and Cambridge University Press have made a great contribution, but not because Lomborg's critique is constructive, for I find it so far off-base as to be quite silly .... Rather, this episode in science shows us the extent to which portions of academe operate on fantastical assumptions and, based on those fantasies, critique whole fields of science beyond their expertise .... If academics cannot do better at sharing an understanding of reality, why should we expect more of society at large and the politicians we elect?

Richard B. Norgaard, Optimists, Pessimists, and Science, BIOSCIENCE, Jan. 2002, at 287, 292 (book review).

87. See, e.g., The Ultimate Resource, supra note 3; The Ultimate RESOURCE 2, supra note 3.

88. See, e.g., LOMBORG, supra note 1.

89. See, e.g., Ronald Bailey, Ecoscam: The False Prophets of ECOLOGICAL APOCALYPSE (1994).

90. See Stephen H. Schneider, Hostile Climate: On Bjorn Lomborg and Climate Change, GRIST MAG., http://www.gristmagazine.com/books/Schneider 121201.asp (Dec. 12, 2001).

91. See Dutton, supra note 6. 
book review issue, offered an evaluation of Lomborg's compendium of scientific information by Judge Alex Kozinski..$^{92}$ Perhaps not surprisingly, Judge Kozinski was unable to muster a single critical comment about the book. ${ }^{93}$ Indeed, he appeared to accept Lomborg's interpretation of scientific data primarily on the strength of the fact that Lomborg was not a scientist. ${ }^{94}$

Such dismissal of scientists' opinions has become increasingly common and suggests that tribal dynamics are at work here. Conservation biologists, atmospheric scientists, geologists, toxicologists, and other physical scientists seem to have been lumped into the tree hugger tribe and ascribed impure motives. Lomborg, for instance, questions the traditional authority of scientists by arguing that they, too, have financial incentives to distort knowledge about environmental problems: "There are many grants at stake," he writes. ${ }^{95}$ More bluntly, Todd Zywicki contends that "the striking tendency of environmental interest groups to dramatically and consistently misrepresent scientific information and economic evidence so as to mislead and 'scare' the public," arises from the fact that, "like any other rentseeking group, the behavior of environmental interest groups can be best explained by the desire to use the coercive power of the state to allow some individuals to pursue utility and wealth and to force other individuals to subsidize these preferences." 6

Accepting such a viewpoint leads to cynicism about all scientific communications, opening the way for federal judges without relevant academic or professional training to make pithy pronouncements about complex scientific subjects, as if their opinion was no different in kind from that of the

92. Kozinski, supra note 6, at 1742 .

93. See id. at 1763 (describing Lomborg's book as "based on facts and figures that no one seriously disputes").

94. See id. at 1750 (emphasizing that Lomborg approaches his sources with "a statistician's eye" which leads him to "very different conclusions" than orthodox interpretations of scientific information).

95. LOMBORG, supra note 1 , at 254.

96. See TODD J. ZYWICKI, BAPTISTS? THE POLITICAL ECONOMY OF POLITICAL ENVIRONMENTAL INTEREST GROUPS 2 (George Mason University Law and Economics Working Paper Series No. 02-23, 2002), http://papers.ssrn.com/sol3/papers.cfm?abstract_id=334341 (last visited Mar. 2, 2003). Like Kozinski, Zywicki relies on The Skeptical Environmentalist as support for the claim that "environmental interest groups have proven themselves dramatically wrong on almost every environmental and economic trend since their inception in the 1970s." Id. at 8. 
thousands of scientists who jointly form the IPCC. ${ }^{97}$ For better or worse, the conclusions of scientists have increasingly joined the marketplace of ideas, are treated as commodities just like any other expression of self-interested political opinion, and are subject to acceptance or rejection based on little more than perceived tribal affiliation. ${ }^{98}$ As a result, the prospects for science-driven consensus on environmental policy-making issues grow dim.

\section{The Hidden Debate}

A final reason that consensus regarding scientific knowledge may have little effect on tribalism is that disputes over empirical knowledge can serve as proxies for more fundamental disputes over values. Unlike other divisive policy issues such as abortion, environmental law and policy will never just be driven by values or morals. Environmental discussions necessarily concern questions about the extent of a harm, its likely consequences, and the costs of avoidance; thus the discussion generally does (indeed must) take place in primarily empirical terms. For reasons related to the competing worldviews account of Section II.B., however, environmental policies will never just be driven by the facts, either. As Donald Braman and Dan Kahan have noted, when active participants in environmental debates discuss scientific and economic issues, they are not only "arguing about what empirical data to trust; they are [also] attempting to push certain risks to the center of the perceptual stage and to banish

97. Judge Kozinski's biography states that he received a Bachelor of Arts degree prior to his legal training and does not mention any work experience in the sciences. See Fed. Judicial Ctr., Judges of the United States Courts, at http://air.fjc.gov/newweb/jnetweb.nsf/fjc_bio (last visited Mar. 2, 2003).

98. Judge Kozinski, for instance, seems to have taken special comfort in the fact that Ronald Bailey of the Competitive Enterprise Institute offered a positive review of The Skeptical Environmentalist, see Kozinski, supra note 6, at 1762 n.71, while Paul Ehrlich of Stanford University's biology department offered a negative review, see id. at 1759 n.57. With tribal alliances in place, Judge Kozinski merely had to choose his side, which he seems to have done by dismissing Ehrlich as "the Jar Jar Binks of the environmentalist movement." Id. Similar tribal allegiance can be seen in Judge Kozinski's simultaneous complaint that the predictive models of environmental scientists "often reflect, not reality, but the pre-conceptions of the model's creators," id. at 1743, and his failure to consider how the same criticism applies to the models of bean counters which, after all, attempt to predict both ecological and economic consequences of global climate change and mitigation strategies. See id. at 1756 (endorsing without qualification Lomborg's discussion of the costs and benefits of the Kyoto Protocol). 
others to the wings because risk regulation is pregnant with visions of the good society."

Proponents of eco-pragmatism are well aware that environmental policy is unavoidably value-laden in this manner. Indeed, a chief aim of eco-pragmatism is "to keep us firmly aware of the complexity of our values, but prevent that complexity from entangling us to the point of inaction." 100 At times, both bean counters and tree huggers create the impression of a purely scientific divide-a policy-making space that is polarized only by competing scientific descriptions, and not also by competing values. The public is left sensing that it must choose whom to believe, rather than judge how to proceed, and these are fundamentally different decisions. The problem with this approach to environmental advocacy is that the value divide remains operative, however careful advocates are to describe their positions in purely consequentialist terms, whether scientific or economic. Thus, consensus on factual issues in environmental law and policy may be impeded not only by the uncertainty and manipulability of science, but also because reaching full agreement on factual issues may require full agreement on the deeper, submerged moral and cultural divides as well.

\section{CONCLUSION}

What is most distressing about the cutting gate in environmental law and policy is that it seems to prevent the emergence of a strong, effective lobbying force for a sensible middle ground. Public opinion seems overwhelmingly to favor both environmental protection as a national goal101 and fiscal prudence in the effectuation of that goal. ${ }^{102}$ Yet few if any

99. Donald Braman \& Dan M. Kahan, More Statistics, Less PERSUASION: A CULTURAL THEORY OF GUN-RISK PERCEPTIONS 30 (Public Law \& Legal Theory Working Paper, 2001), http://www.law.uchicago.edu/academics /circulation5.pdf (emphasis added) (last visited Mar. 2, 2003).

100. FARBER, supra note 16, at 201.

101. See Daniel A. Farber, Environmental Protection as a Learning Experience, 27 LOY. L.A. L. REv. 791, 792-93 (1994) (reviewing evidence that "the goals of environmental law" are "deeply entrenched").

102. See FARBER, supra note 16, at 200 ("Economic growth is not something we are prepared to abandon in the name of environmental protection."). While Farber also presents evidence that would seem to cast doubt on this claim (see $i d$. at 2 , citing survey evidence in which 80 percent of respondents agreed that "[p]rotecting the environment is so important that regulations and standards cannot be too high, and continuing environmental improvements must be 
advocacy organizations are able to seize that middle ground with success. Instead, their voices seem at great risk of being lost amidst the shrill tribal cacophony of tree huggers and bean counters, which often simply drowns out the call for ecopragmatic approaches. Because of the dynamics described in the preceding sections, complex, uncertain, and value-laden issues frequently are presented to the public in terms that are unduly reductionist, absolutist, or lacking in candor. Global climate change, for instance, is often said to threaten dire consequences, without attention to the likelihood and confidence limits surrounding such possibilities. ${ }^{103}$ In turn, the Kyoto Protocol is said to require rolling back the standard of living, without explanation as to what assumptions are driving that conclusion or, indeed, what the "standard of living" measures and excludes. ${ }^{104}$ Other examples of poorly framed environmental issues abound. ${ }^{105}$

To some extent, such advocacy strategies simply reflect the shortcomings of an information-rich, deliberation-poor public forum. ${ }^{106}$ As described above in regard to adversarial policy

made regardless of cost"), the rapid death of Clinton's proposed carbon tax provided pretty clear evidence that green talk is cheap.

103. See FARBER, supra note 16, at 177-78 (describing the disjunction between the highly publicized catastrophic risks of climate change and the extent of scientific knowledge regarding such risks).

104. Consistent with that approach, Lomborg recently offered a New York Times editorial, entitled "The Environmentalists Are Wrong," in which he attempted to summarize the mind-boggling complexity of global climate change in four precious columns of text. See Bjørn Lomborg, Editorial, The Environmentalists Are Wrong, N.Y. TIMES, Aug. 26, 2002, at A15. His conclusion is that "[d]espite our intuition that we need to do something drastic about global warming, economic analyses show that it will be far more expensive to cut carbon dioxide emissions radically than to pay the costs of adapting to the increased temperatures." Id. What Lomborg failed to disclose is that the expense of cutting carbon dioxide emissions includes the opportunity cost of foregone Ford Excursions, and the costs of adaptation include the premature expiration of thousands of future human lives, particularly in the developing world, both of which have been valued by Lomborg's "economic analyses" in a manner that deserves inspection and debate. See Kysar, supra note 52, at 44-51. Put differently, there is a moral discussion to be had here, one that seems at risk of being lost amidst competing strategies of alarmism and reductionism.

105. See, e.g., Rebecca Bratspies, The Illusion of Care: Regulation, Uncertainty, and Genetically Modified Food Crops, 10 N.Y.U. ENVTL. L.J. 297, 298 (2002) (noting that debate over genetically modified organisms is characterized by the "rhetorical excesses of a 'new green revolution' and 'Frankenstein foods"').

106. See KRAFT, supra note 64 , at 17 ("Unfortunately, contemporary politics has created a demand for simple ideas expressed in news conference 
making, ${ }^{107}$ under such conditions, fundraising, constituency building, and other aspects of political entrepreneurship may in fact be pursued most effectively by reducing complex scientific issues to simplistic stories of good versus evil (i.e., publicspirited environmentalists versus greed-infused multinational corporations). ${ }^{108}$ In a parallel fashion, business interests often stand to gain more by portraying environmental causes as excessively romantic, scientifically unfounded, and diametrically opposed to national welfare than they do by engaging publicly in a balanced, reasoned assessment of social options. ${ }^{109}$ Unfortunately, mass media presentation of environmental issues rarely delves below these symmetric sound bite strategies. ${ }^{110}$ Poised between these extremes, ecopragmatic proposals become vulnerable to double-demonization by tree huggers and bean counters alike, undermining their ability to persuade a public that otherwise might be quite receptive. ${ }^{111}$ The result is a public that is deeply, but understandably, confused about the state of environmental quality in the early twenty-first century, about the relationship

sound bites and an impatience to work through complex scientific issues and tough policy choices."); Roger A. Pielke, Jr., Policy, Politics and Perspective: The Scientific Community Must Distinguish Analysis from Advocacy, 416 NATURE 367, 368 (2002) ("Science is becoming yet another playing field for power politics, complete with the trappings of media spin and a win-at-allcosts attitude. Sadly, much of what science can offer policy-makers, and hence society, is being lost.").

107. See supra text accompanying notes 38-40.

108. See Zywicki, supra note 96, at 17 ("Because bigger scares lead to bigger contributions, scaring the public is an effective mechanism for environmental activists to build their war chests and to sustain their organizations.").

109. Cf. FARBER, supra note 16, at 35 ("Economists consider environmentalists to be hopeless romantics, eager to pursue their own personal values without heeding the cost to society.").

110. As Kraft notes,

[S]cientific uncertainties often are exploited to strengthen particular positions on the issues. Highly vocal critics of environmentalists, from scientists such as Richard Lindzen and S. Fred Singer to conservative talk show host Rush Limbaugh, fire polemical broadsides at their adversaries on climate change issues. From their perspective, environmentalists are guilty of "inflammatory claims," "doomsday rhetoric," and "environmental overkill." These exchanges are intriguing but rarely enlightening, and they often confuse both the scientific and policy issues.

KRAFT, supra note 64, at 17.

111. Cf. J.B. Ruhl, Is the Endangered Species Act Eco-Pragmatic?, 87 MINN. L. REV. 885,889 (2003) (" $[E]$ co-pragmatism finds few friends in the conventional opposing camps of environmental policy."). 
between present action and future environmental quality, and about the possibilities and limits of government regulation..$^{112}$

For a variety of reasons, therefore, public advocacy in environmental debates often does not allow the lay observer to identify what the relevant tradeoffs are, where the uncertainties lie, and what corresponding policy proposals best resonate with her individual values. Farber's brand of ecopragmatism, on the other hand, seems directed at achieving precisely that type of intellectual candor. Recognizing the futility of attempting to resolve ultimate philosophical issues, Farber instead advocates an eclectic, pluralistic approach that attempts to resolve disputes by inviting the expression of multiple values, perspectives, and concerns. Such an approach makes good sense. After all, bean counters are correct that the public's demand for environmental, health, and safety regulation is sometimes based on poor information or cognitive error. 113 Simultaneously, tree huggers also are correct that narrow forms of cost-benefit analysis ignore legitimate public values. ${ }^{114}$ Presumably, responsible policy makers would wish neither to give effect to ill-informed fears nor to enshrine moral obtuseness. As Farber puts it, "[I]n reality, both market and political mechanisms have flaws as expression of the public interest. The real question is not whether to follow one while ignoring the other, but how to make the best use of both to guide public policy."115

This contention strikes us as fundamentally sound, but we doubt whether such an eco-pragmatic approach can successfully be heard in a marketplace of ideas dominated by environmental tribalism. We are not so naive to think, for instance, that an ethic of intellectual honesty will somehow miraculously sweep through the channels of advocacy to alter the American political marketplace. Nor do we expect environmental tribalism to vanish in a fit of group hugs and tearful acknowledgment that competing creeds are both relevant and significant to environmental policy making. Rather, we believe that the various dynamics we have described that drive environmental tribalism are related to structural features of our democracy and our culture that go

112. See FARBER, supra note 16 , at 72 (observing that "[i]n reality, most people's feelings are a confused mixture of tree hugger and bean counter").

113. See supra text accompanying notes 46-53.

114. See supra text accompanying notes 54-56.

115. FARBER, supra note 16 , at 42 . 
beyond the framework of environmental law and policy. To be sure, public understanding of environmental issues would benefit tremendously from a general program of ecological literacy, ${ }^{116}$ as well as from a commitment to government funding of independent scientific research and its public dissemination. Environmental issues are especially, perhaps uniquely, prone to cutting gate dynamics given their combination of complex and uncertain scientific information with policy decisions that must somehow choose among competing values and worldviews. It is therefore no surprise that communication of scientific knowledge by advocacy groups and mass media provides a recipe for polarization and confusion.

We could go on in this vein, but recounting a wish list of deliberation-enhancing changes to our democratic structure serves little immediate practical purpose, however desirable such changes may be in the abstract. ${ }^{117}$ Above all, we wish to be pragmatic concerning the problems facing eco-pragmatism. The question therefore becomes strategic: Where can one most effectively further the goals of eco-pragmatism? Given the preceding analysis, the answer seems to us fairly obvious: It must be below the public advocacy level. While a crude model, one can think of environmental policy formation as a two-level game, acted out at one level by the public advocacy debate and, at a less visible level, by practical debates of implementation within the agencies, congressional committees, and other government bodies charged with regulatory design, enforcement, and oversight, as well as among the various nonstate actors that remain interested and active beyond the public advocacy level (the so-called "players"). We believe that it is at this second stage of the policy cycle that one might expect eco-pragmatism to flourish. ${ }^{118}$

116. In this regard, it is interesting to note that in Australia (where Jim Salzman is spending the year), a country with relatively strong environmental groups, publication of Lomborg's book was very much a non-event, hardly raising a ripple of protest or notice. Perhaps this is because there is strong general agreement across Australia over the magnitude of environmental challenges the country faces, from loss of biodiversity and ozone depletion to salinity and soil loss.

117. For a thorough, insightful survey of much of the relevant political theory literature, see Christopher H. Schroeder, Deliberative Democracy's Attempt to Turn Politics into Law, LAW \& CONTEMP. PROBS., Summer 2002, at 95.

118. See Farber, supra note 37, at 872 ("Given that polarization is such a major problem in environmental law, one particularly important avenue for 
Indeed, to some extent, eco-pragmatism already has begun to take hold in precisely this manner. As we alluded to earlier, if one looks at standard setting, zoning decisions, and many other instances of environmental policy implementation, one often finds bureaucrats and hostile advocates adopting creative interpretations of statutes or other discretionary methods to avoid extremist results. ${ }^{119}$ Moreover, there seems to be widespread support among various interested parties for innovative "radical middle" programs such as the increased use of Habitat Conservation Plans under the Endangered Species Act during the Clinton administration. ${ }^{120}$ Accordingly, considerable academic momentum has gathered behind the prospect of formalizing such regulatory "reinvention" by replacing traditional combative, adversarial rule-making proceedings with innovative, cooperative approaches that presumably would be more conducive to pragmatic decision making. ${ }^{121}$

Thus the target audience for appeals to eco-pragmatic decision making may well be neither the Greenpeaces of the world, nor the Competitive Enterprise Institutes, nor even the general public. Although we are emboldened by the fiery words of Ruhl's "Manifesto for the Radical Middle"122 and Farber's persuasive arguments for eco-pragmatism, we remain

progress is to defuse the conflicts by finding implementation methods that accommodate competing concerns.").

119. See Daniel A. Farber, Taking Slippage Seriously: Noncompliance and Creative Compliance in Environmental Law, 23 HARV. ENVTL. L. REv. 297, 305-09 (1999).

120. See Farber, supra note 40, at 64-65 (describing the success of Habitat Conservation Plans); Ruhl, supra note 111, at 890 (stating that Bruce Babbitt, Secretary of the Department of the Interior and a chief architect of the increased use of Habitat Conservation Plans is "the most valuable ecopragmatist of the 20th century").

121. As Farber puts it, "[r] einvention [of the regulatory process] is all the rage today." Farber, supra note 40, at 61 . Farber introduces three different strands of the emerging reconceptualization of the regulatory process: selfregulatory efforts by firms; multilateral negotiation among firms, regulators, and other interested parties; and a bilateral model in which firms and regulators negotiate while other interested parties assume a more limited, watchdog role. See id. at 62 .

122. In Ruhl's own words,

I have in mind an aggressive middle. An aggressive middle-what I will call, for purposes of rallying the troops, the radical middle-is a bully in its own right. It not only refuses to compromise its compromise position, it also roughs up anyone it thinks might dare to do so. It comes out swinging. It fights dirty too. It has passion.

Radical Middle, supra note 20, at 387. 
pessimistic about the prospects for such approaches to take hold in the public forum or as a broad movement. Instead, we believe it is primarily where the rubber meets the road-the actual implementation of environmental policy-that fertile ground for balanced, pragmatic policy development lies. Fittingly, we would expect the cutting gate and tribalism to be weaker dynamics here for the simple reason that regulators are formally insulated from the public forum and majoritarian demands.

As Farber indicated in his contribution to this Symposium, ${ }^{123}$ an important example of such a pragmatic implementation discussion may be found in the current debate over the use of cost-benefit analysis. Despite their awareness of the limitations of cost-benefit analysis (including those associated with valuation, monetization, discounting and other analytical techniques that have proven philosophically divisive in the environmental, health, and safety context), an increasing number of influential scholars, including Kenneth Arrow, ${ }^{124}$ Cass Sunstein,, ${ }^{125}$ Matthew Adler and Eric Posner, ${ }^{126}$ and others have argued in favor of particular, tailored uses of cost-benefit analysis in public decision making. Many of these scholars have advocated "modest, nonsectarian" 127 brands of cost-benefit analysis that encourage regulators and other implementers of public policy to undertake "a full accounting of the

123. See Farber, supra note 37 , at 871 (noting that "the debate over costbenefit analysis has now begun to focus more on its institutional implementation, a topic that lends itself to more reasoned and constructive debate than the earlier battles over the morality of the technique").

124. See, e.g., Kenneth J. Arrow et al., Is There a Role for Cost-Benefit Analysis in Environmental, Health, and Safety Regulation?, 272 SCIENCE 221 (1996); Kenneth J. Arrow \& Robert C. Lind, Uncertainty and the Evaluation of Public Investment Decisions, 60 AM. ECON. REv. 364, 366-67 (1970).

125. See, e.g., CASS R. SUnSTEIN, THE COST-BENEFit STATE: THE Future of REgulatory Protection (2002); Richard H. Pildes \& Cass R. Sunstein, Reinventing the Regulatory State, 62 U. CHI. L. REv. 1 (1995); Cass R. Sunstein, Cognition and Cost-Benefit Analysis, 29 J. LEGAL STUD. 1059 (2000); Cass R. Sunstein, Cost-Benefit Default Principles, 99 MICH. L. REV. 1651 (2001).

126. See, e.g., Matthew D. Adler \& Eric A. Posner, Implementing CostBenefit Analysis When Preferences Are Distorted, 29 J. LEGAL STUD. 1105 (2000); Matthew D. Adler \& Eric A. Posner, Rethinking Cost-Benefit Analysis, 109 YALE L.J. 165 (1999).

127. Robert W. Hahn \& Cass R. Sunstein, A New Executive ORder FOR IMPROVING FEDERAL REGULATION? DEEPER AND WIDER COST-BENEFIT ANALYSIS 7 (Chicago-John M. Olin Law \& Economics Working Paper No. 150, 2d Series, 2002). 
consequences of an action, in both quantitative and qualitative terms," 128 without binding themselves to the results like dogmatic mathematicians. For instance, Farber's proposal for limited use of cost-benefit analysis as a tool for identifying when the costs of avoiding environmental harm are "grossly disproportionate to any benefit," 129 bears precisely this tone. Significantly, because the debate over cost-benefit analysis has taken place largely beneath the radar screen of public environmental policy discussions, one would expect ecopragmatic voices such as Farber's to have their best chance of succeeding on a topic just like this. Thoughtful critics of costbenefit analysis continue to identify conceptual, ethical, and practical problems with the practice, ${ }^{130}$ and it remains to be seen how successfully eco-pragmatism's more nuanced, inclusive, and cautious prescriptions for cost-benefit analysis will influence its application. We are guardedly optimistic, though, given that the regulators and other parties who conduct cost-benefit analyses are "behind the scenes," largely removed from the polarizing dynamics that characterize public environmental advocacy.

Make no mistake, the level of public debate remains critically important in setting priorities and shaping initiatives. Indeed, absent a powerful "radical middle" it may well be that extremism is necessary at the level of public advocacy in order to ensure that we ultimately end up in a sensible middle ground at the level of policy implementation. As Brad Karkkainen's contribution to this Symposium makes clear, when environmental policy goals are set deliberately high, they may induce cooperative, information-sharing approaches to implementation by affected parties. ${ }^{131}$

As Farber has noted, however, the fact that the system somehow finds a way of working things out is not, in itself, a vote of confidence. ${ }^{132}$ Indeed, a major goal of eco-pragmatism is specifically to move beyond the environmental policy "mish-

128. Id.

129. See FARBER, supra note 16 , at 131.

130. For one powerful recent critique, see Frank Ackerman \& Lisa Heinzerling, Pricing the Priceless: Cost-Benefit Analysis of Environmental Protection, 150 U. PENN. L. REV. 1553 (2002).

131. See Bradley C. Karkkainen, Adaptive Management and Regulatory Penalty Defaults: Toward a Bounded Pragmatism, 87 MINN. L. REv. 943, 97583 (2003).

132. FARBER, supra note 16 , at 11 . 
mash that neither of the warring sides wanted and the middle had no hand in crafting." 33 In realizing this goal, we suggest that such mish-mash is an unavoidable consequence of the way in which political advocacy is conducted at the turn of the twenty-first century. No matter how widely supported by the public in theory, eco-pragmatism and the radical middle will find it hard going in the national public debate. As we described in Part II, for reasons of institutional design, psychology, and political economy, the cutting gate is alive and well in public environmental debates, neatly herding advocates into pens, strengthening the tribal behavior of tree huggers and bean counters alike, and blocking the emergence of a prominent middle force. Thus, rather than trying to dismantle the cutting gate of public advocacy, eco-pragmatists may be better served by focusing their efforts at the level of policy implementation where such efforts are more likely to be heard and acted upon.

133. Radical Middle, supra note 20 , at 387 . 
